\title{
集約農法が気候変動を緩和する
}

\section{Intensive farming may ease climate change}

JefF TolLefson 2010 年6月 17 日号 Vol. 465 (853)
www.nature.com/news/2010/100615/full/465853a.html

農業の高収率化は、炭素排出量を抑制する。

多くの人は、化学肥料に依存した産業規 模の現代農業を、必要悪と考えているか もしれない。こうしたやり方が、増え続 ける人類を養うかたわら、環境に甚大な 害を及ぼしているからだ。しかし、これ に代わる農法はもっと好ましくないの かもしれない、と結論づける研究がス夕 ンフォード大学 (米国カリフォルニア
州）から発表された。生産性の低い農法 はさらに多くの土地開墾を必要とする ため自然を破壊し、温室効果ガスの排出 量を増大させて生物多様性に大きなダ メージを与えるというのだ。この研究結 果は、農業の集約化を進めることが地球 温暖化対策で重要な役割を果たすこと を示唆している ${ }^{1}$ 。
研究チームは、緑の革命」を終えた(集 約農法が普及した）現実世界の温室効果 ガス排出量のモデル化と、作物収量と生 活水準を数十年前のレベルにとどめた場 合と作物収量のみをとどめた場合という

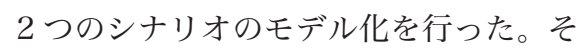
の結果、集約農法では温室効果ガス排出 量は増加するが、天然の土壤、草原、森 林に炭素を維持する土地保全の効果で 「お釣り」がくることが示された。

この論文の著者の 1 人であり、ス夕 ンフォード大学で農業を研究する David Lobell は、「当初は、増加を続ける農業 による温室効果ガス排出量より、土地利 用による排出量の抑制が上回るのかどう か、実のところわかりませんでした」と 打ち明ける。確かに温室効果ガスの排出 量は、集約農法で利用される肥料により、 最終的に増加した。合計すると、人類に 


\section{温室効果ガス排出量}

2つのシナリオを現実世界と比較することにより、農業からの総炭素排出量が集約農法によって 実際に抑制されていることが示唆された (SOL=生活水準)。
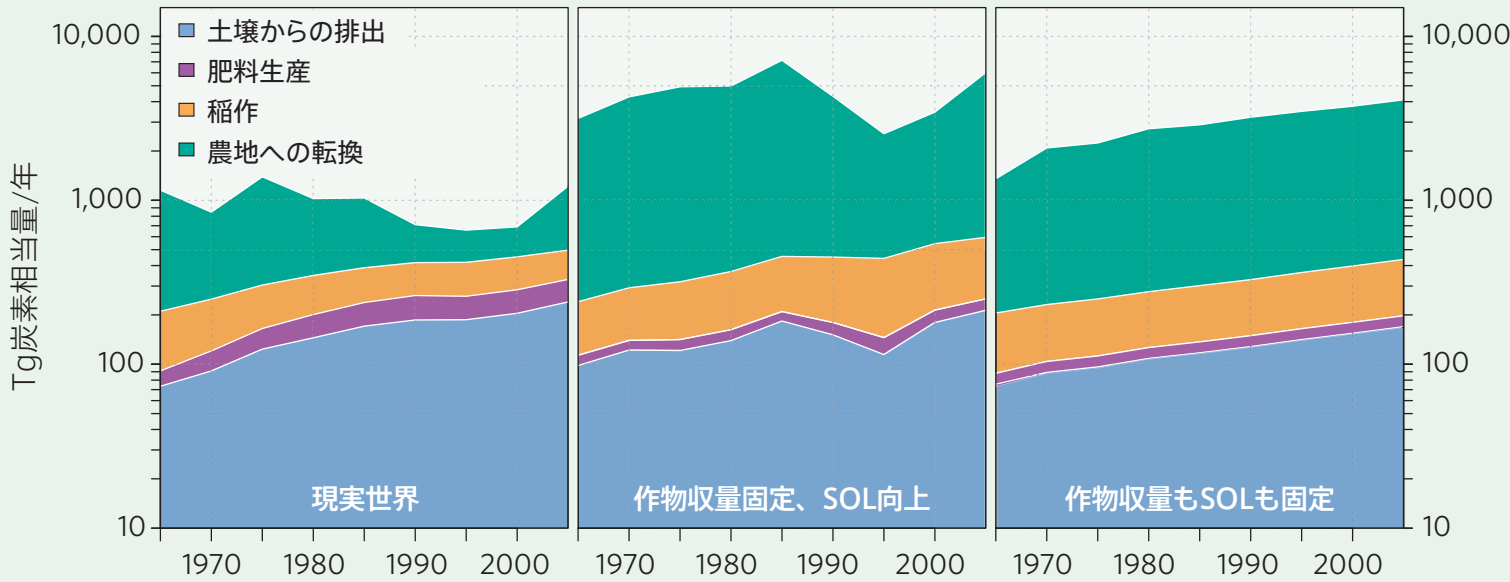

よる 2005 年の総排出量の 10 ～ 12 パー セントが農業によるものだった。

しかし、Lobellによれば、その収支 は「黒字」になった、つまり「炭素排出 抑制がかなり大きかった」というのだ。 ほかのすべての条件が同じだとすると、 1961 年から 2005 年までの農業の進歩 によりロシアより広い面積が開発から守 られ、二酸化炭素 590 ギガトンに相当 する排出量が抑制されたことがわかっ た。これは、産業革命が始まって以降の 総排出量のほぼ 3 分の 1 に当たる。

作物収量の増大が森林その他の自然の 土地を守るという考え方は、緑の革命の 父であり、米国の植物科学者だった故 Norman Borlaug にさかのぼる。Lobell らは、Borlaug 仮説として知られるこの 効果について定量化を行い、それによる 温室効果ガス排出削減量を試算した。

研究チームによれば、1961 年から 2005 年までに、世界の人口は 31 億人 から 65 億人へと 111 パーセント増加し た一方、作物収量は 135 パーセント増加 したという。しかしながら、増加した農 地はわずか 27 パーセントで、 9 億 6000 万ヘクタールから約 12 億ヘクタールに なつたにすぎない。

研究チームは、かつての技術で現在の
世界を養うのに必要な農地面積を算出 しようと、まず、作物収量を 1961 年の 水準に固定し人口と生活水準を一気に 高めてみた。この場合、現実世界と比べ ると、肥料使用による排出量は少なかっ たが、食糧生産に必要な農地の面積が 18 億ヘクタール近くも増大した。第二 のシナリオでは、作物収量と生活水準を ともに 1961 年のレベルに固定したとこ ろ、農地転換と温室効果ガス排出量に関 する影響は、最初のシナリオのほぼ半 分にとどまったが、それでも現実世界 での実際の影響よりなお大きかった（上 図「温室効果ガス排出量」を参照)。

最後に、研究チームは 1961 年以降、 農業研究開発に投じられた約 1 兆 2000 億ドル（約 10 兆円）の資金を分析した。 研究対象期間全体で平均すると、農産物 収量への投資は、二酸化炭素 1 トン当 たり約 4 ドルのコストで炭素の排出量 を削減した。これは、ヨーロッパの炭素 取引の枠組みによる排出権価格実勢值の 4 分の 1 未満だ。

作物収量が上昇し続ければ環境面のメ リットはさらに大きくなる、と研究チー ムはいう。例えば、昨年、地球温暖化共 同研究機構 (米国メリーランド州カレッ ジパーク）の研究チームは、土地利用の
シナリオを分析し、作物収量の増加が風 力や太陽光などのエネルギー技術に匹敵 する排出量削減をもたらす可能性を明ら かにした ${ }^{2}$ 。

ケンブリッジ大学 (英国) の環境保全 科学者 Andrew Balmford は、「この研 究では、何よりも、農業研究への投資、 特に開発途上国への投資が重要である としています」と語る。ミネソタ大学 （米国セントポール）の生態学者 David Tilman が行っている分析によれば、第 二の緑の革命が起こらないかぎり、増え 続ける人類を養うためには、2050 年ま でに約 15 億〜 20 億ヘクタールを新た に開墾する必要があるという。しかし幸 い、開発途上国にはまだ非効率的な農地 があり収量増大が大いに見込める可能 性がある、と Tilman は話す。「地球を 救いたいなら、世界に食糧を供給しなけ ればなりません。そして、それに最も貢 献できるのは、こうした発展途上の最貧 国なのです」。

(翻訳：小林盛方)

1. J. A. Burney et al. Proc. Natl Acad. Sci. USA 107, 12052-12057 (2010).

2. M. Wise et al. Science 324, 1183-1186 (2009). 